European journal of American studies

Special Issue: Immigration

\title{
The Minutemen and Anti-immigration Attitudes in California
}

\section{Frédérick Douzet}

\section{(2) OpenEdition \\ Journals}

Electronic version

URL: https://journals.openedition.org/ejas/7655

DOI: $10.4000 /$ ejas.7655

ISSN: 1991-9336

Publisher

European Association for American Studies

\section{Electronic reference}

Frédérick Douzet, "The Minutemen and Anti-immigration Attitudes in California", European journal of American studies [Online], 4-3 | 2009, document 2, Online since 01 December 2009, connection on 08 July 2021. URL: http://journals.openedition.org/ejas/7655 ; DOI: https://doi.org/10.4000/ejas.7655

This text was automatically generated on 8 July 2021 .

Creative Commons License 


\title{
The Minutemen and Anti- immigration Attitudes in California
}

\author{
Frédérick Douzet
}

\section{Introduction}

1 On April 1st 2005, Jim Gildchrist launched the Minutemen Project movement ${ }^{1}$, which was soon to ramify into dozens of small organizations and inspire thousands of volunteers who were ready to invest their time patrolling the U.S.-Mexico border in a largely vain attempt to stop illegal immigration to the United States. ${ }^{2}$ This motley gung-ho crowd dressed in camouflage and carrying guns attracted worldwide attention and sarcastic comments from the media and President Bush himself, who publicly called them "vigilantes". ${ }^{3}$ Yet in the midst of heated debates over illegal immigration and comprehensive immigration reform, the minutemen offer an interesting window into anti-immigration sentiment in California. The variety of their motivations and origins echoes to the complexity and conflicting nature of views on immigration. Shortly after Lieutenant Governor Cruz Bustamante had prematurely declared "hate politics" over in the Golden State in 1999, anti-immigration sentiment has been on the rise again. It has come back as a wedge issue in California politics in the mid-2000s. Given the circumstances, which are in many ways different from the 1990s, the question we must ask here is "why?"

2 In 1994, Governor Pete Wilson was up for reelection in a state struggling to recover from an economic recession worsened by drastic cuts in defense contracts. In the meantime, the state was facing a tremendous population growth mostly driven by massive immigration from Latin America and Asia. In a context of growing concern about immigrants being a drain on the state and local government budget, Wilson endorsed immigration as the primary issue of his platform to build political capital and sponsored an anti-immigration initiative to help his reelection, Proposition 187. Antiimmigration attitudes grew in California during the 1990s and culminated with the passage of Prop. 187 by a large majority of Californians, which included a substantial a substantial share of African-Americans and second generation immigrants. ${ }^{4}$ Had it not been invalidated by a Federal court, the law would have denied undocumented 
immigrants social services, health care and education. Although the debate about immigration had quieted down for a few years, the questions that arose in the mid-1990s are the same that are asked ten years later. Why would a state that had seemed so unconcerned about immigration and demographic changes in the previous decades become so frantic about illegal immigrants?

Based on the causes of the anti-immigration debate of the 1990s, this paper offers to analyze the causes of the rise of anti-immigrant attitudes in California in the mid-2000s through the analysis of the minutemen's perceptions. Drawing from my extensive field work at the California-Mexico border, I argue that it is a somewhat different set of circumstances that has led to the rise of anti-immigration attitudes in California in the mid-2000s. By using immigration as a wedge issue in the early 1990s, Pete Wilson ensured his reelection but did not succeed in his attempt to make it a national issue likely to win him the presidential nomination. Yet this government initiative clearly stirred up resentment for political gain at the popular level.

In a reverse "bottom-up" dynamic, from 2004 to 2006, a grassroots movement organized to put pressure on the federal government to strengthen the border. When the issue of immigration finally hit the national stage at the end of 2005, it trickled down again to California, stirring dormant passions about the latinization of the state.

5 This paper is based on interviews at the border with elected officials, border patrol officers and community leaders, as well as five days of immersion with minutemen organizations in the summer of 2006. I attended a camp organized by the Minuteman Civil Defense Corps in Campo, California ${ }^{5}$. I went along border watch operations during daytime and nighttime, attended briefing meetings and went along a flag operation in Jacumba, California. I also met with the Campo minutemen and several volunteers from various groups patrolling the border east of San Diego area. I conducted geographic observation and semi-directive interviews.

6 This analysis uses the geopolitical approach, meaning the study of power rivalries on territories. More than the reality of the immigration challenge to the U.S., I focus on the perceptions of immigrants and immigration among the minutemen in order to understand how and why the debate over immigration has regained such vitality in the mid-2000s in California.

\section{Anti-Immigration in the 1990 s}

7 Karin Mac Donald and Bruce E. Cain analyzed the vote by county for Proposition 187 and compared it to the vote for Proposition 63, a measure that declared English the official language of California in 1986, which was overwhelmingly approved by 73 percent of the voters. They found that Prop.187 divided voters along party, racial, ethnic, educational and income lines: "Counties with larger shares of Republicans, whites, noncollege educated, foreign born, and the less affluent tended to support Prop. 187, and those with larger shares of Democrats, Asians and Pacific Islanders, Latinos, the college educated and the affluent were less inclined to support Prop.187." 6

8 The drastic demographic changes in Southern California and the Bay Area over the past two decades had raised concerns about the future of American identity among some Americans. The vast majority of immigrants moving into California since the 1970s were non-white and non-English speaking, coming in almost equal share from Latin America and Asia. In addition, soon after the 1986 general amnesty, Mexican undocumented immigrants started flowing in greater numbers into the state. Demographic projections were equally worrying for some, predicting there would be no 
racial majority in the state at the beginning of the twenty-first century, which indeed turned out to be the case. Although racial nativism might have motivated part of the voters, it has to be counterbalanced with other more pragmatic considerations considering the timing of the vote.

9 At the end of the 1980s, California's economic situation had seriously deteriorated. In addition to the downturn of the American economy, the drastic cuts in defense contracts and base closures drove unemployment up, heightened job insecurity, and eroded incomes. This context played a role in shifting public attitudes against undocumented immigrants who were perceived as competing for jobs and driving wages down. In that sense, the vote for Prop 187 was probably less motivated by a racial nativism, which aims at "keeping the country's racial stock pure," but rather by political nativism, with "pragmatic policy considerations such as keeping citizen unemployment at a manageable level, preserving median income levels, maintaining a certain quality of life, trying to hold down the costs of public services and the like."

The divide between white and minority voters has later become clearer on Prop. 209 (1996), which dismantled affirmative action programs and Prop. 227 (1998) which put an end to bilingual education. This could also be seen as a result of party strategy to use immigration and race as a wedge issue. It was clearly part of Governor's Pete Wilson's successful strategy for reelection in 1994 and his unsuccessful attempt to win the Republican nomination for the 1996 presidential election.

11 At the turn of the century, anti-immigration attitudes had largely quieted down. In 1999, Governor Gray Davis dropped the state's appeal of the federal court decision that overturned Proposition 187. Californians, encouraged by a booming economy, seemed to have overall adjusted to the new diversity. Legislature term limits and redistricting had helped the election of many Latino and Asian representatives across the state. In addition to providing the main labor source for the agriculture industry, Latino immigrants became pivotal to the economy, regardless of the fiscal costs they might have engendered. They worked in most of the people's garden, in house construction and in restaurant kitchens. In 2005, the city of Los Angeles elected its first Latino mayor since 1872, thanks to the support of a wide coalition of white progressives and AfricanAmerican voters. ${ }^{8}$

Meanwhile, the political instrumentalization of immigration backfired on the California Republicans. Prop. 187 helped Wilson win in the short run but encouraged more Latino immigrants to apply for naturalization and to register to vote. The Latino electorate substantially increased and helped change the political dynamic of the state. In the 1990s, more than one million Latinos registered to vote for the first time in California. Yet the surge in Latino voters cannot explain alone the shift from a red Republican state to a blue Democratic state. Republican representatives in California have become more conservative, on immigration and social and cultural issues such as abortion and same sex marriage. This altered the middle-of-the-road image of their party, making it very difficult for them to win statewide elections. ${ }^{9}$

When the anti-immigration issue erupted again in 2005 , it came as a surprise to many observers in the state. The rise of the minutemen at the California border, who revived the issue, was widely perceived as an anachronism. The economy was then doing much better than in the early 1990s and despite the downturn of the dotcom industry, it had stabilized. People seemed to have adjusted to diversity and most of the laws providing 
preferential treatment to minorities had been dismantled. In the meantime, California had elected an immigrant governor and had become a state with no racial majority.

In short, the 1994 anti-immigration debate was a Californian issue, started by a governor through a government initiative in the context of an economic recession. The primary goal was for the governor to win reelection and possibly the presidential nomination. The 2004-2006 immigration debate, however, was started by a grassroots movement, in the context of a stabilized and favorable economy, in order to influence Congress on a debate that soon became national. In that context, it is important to understand the perceptions of the minutemen in order to explain the resurgence of anti-immigration attitudes in the mid-2000s in California.

3. Who Are the Minutemen?

15 The Minutemen Project is one of the citizen-border patrol groups started out of frustration with the United States immigration policy. It originated mostly from Arizona and rapidly became the most visible group drawing a great number of volunteers through media coverage and internet strategy. Founding father Jim Gildchrist's goal has been to attract attention to the situation at the border and lobby the Washington administration for immigration policy reform. He has therefore concentrated most on highly visible demonstrations as opposed to ground operations, which were launched by other minutemen groups. Chris Simcox, who had teamed up with Gildchrist to found the Minutemen Project, left the organization and founded the Minuteman Civil Defense Corps (MCDC), a group more focused on border action. Other members, more interested in leading operations than following orders, have left both organizations to create their own groups. According to the comments by several members of the California branch, there have been competing egos in the organization. When I first met them, MCDC leader Carl Braun informed the group that Tim Donnelly had left for " personal reasons," which turned out to be the creation of his own civilian border patrol group, the Minuteman Party. The minutemen groups are very diverse. Some, such as the Campo minutemen, are very local, rather small with a loose informal structure, while others such as the MCDC, are highly structured with regular activities and up-to-date websites,.

16 The MCDC organizes regular gatherings at the border and offers training to new volunteers. I spent a few days of full immersion in their group, attending briefings and night surveillance. The MCDC is one of the largest, most visible and structured minutemen group. While the Minutemen Project mostly focusses on demonstrations and lobby activities, the MCDC takes action at the border and encourages members to directly participate in stopping immigration. It therefore seemed to me a good way to meet highly motivated people willing to contribute their time to stop immigration in order to study their motives. I also met with border patrol officers and other minutemen organizations. I had the opportunity to discuss issues at length with volunteers and interview most of them separately at the California Border in July 2006.

17 The minutemen are often portrayed in the media as a bunch of crazy people, if not racist, with too much time on their hands. Judging from the groups I have encountered, they could easily fit some of these stereotypes. Most of them carry and love guns, venerate the flag, dress in military camouflage clothes, drive huge pick-up trucks, support the troops in Iraq and are overtly against illegal immigration. Many of them have some background in the military, are former marines or wanna-be soldiers who 
have missed an opportunity to join the army. All of them declared admiring the military and feeling proud to serve their country.

Although most of them deny being racist, many showed clear nativism and ethnic jokes kept being made about undocumented Mexicans. For most of the campers, the country is facing an invasion and they are waging a cultural war against people who do not respect the law, refuse to assimilate and learn the language, and who send their money back home. According to the Southern Poverty Law Center, the minutemen are not a "hate group" but fall into the new category of "extremist nativist" groups. ${ }^{10}$ Yet there is growing concern that their type of rhetoric and action might attract white supremacists and other dangerous individuals. The long history of violence and racial hatred that paved the formation of the U.S.-Mexico border makes many observers suspicious about the minutemen's activities and their potential for racial hatred. Although minutemen leaders claim to carefully screen their new applicants, there have been a number of neo-Nazis and white supremacists who have joined minutemen organizations and who carry guns without being checked for permits.

Yet the MCDC camp I attended in mid-July 2006 in Campo revealed a much more diverse crowd than I was expecting. The members had a wide range of motives. They repeatedly denied being racist. Interestingly, there were some foreigners, mixed couples and minorities among them. Joseph Fong, a minuteman from Singapore, explained he had waited years before he could get his visa to the United States. "Why should people who break the law jump in front of the line?" The group leader, Carl Braun, has even been a diversity recruiter for women and minorities senior for level jobs for over 25 years. He has therefore spent most of his life helping minorities go through the glass ceiling and raise to senior level positions.

All the minutemen I met had in common a frustration with the Bush administration and its lack of action towards undocumented immigration. They all talked about immigration in terms of an invasion that was ignored by the government. They therefore share a sense of standing-up for their country, in the typically voluntarist American way, making up for the weakness of their government. "Do you know what we call these? Bush booties!" laughed Dan Russel, a Campo minuteman, proudly waving pieces of blankets used by Mexicans to cover their traces in the sand. "Everything that's bad we call 'Bush'," he joked, admitting to always voting Republican no matter how much he disagrees with the administration on immigration.

Despite the omnipresence of guns, the activities displayed most of these groups do appear rather harmless on the ground. The minutemen claim to be a peaceful organization. They lobby the Washington administration, watch the border, or pass out flyers at day-laborer pick-up sites. These flyers carry messages threatening to denounce employers who hire undocumented immigrants. Many minutemen also volunteer for minor repairs on the fence or display American flags at the border and signs with straightforward messages such as: "Stay home, this is not your country!" or "Illegals go home!"

22 On July 15 at 6:00 A.M., the group I was following left for the neighboring city of Jacumba, a large immigrant community, to display American flags with little messages on a 3 feet high fence along the border. When I questioned the function of the flags, an organizer answered, “It won't stop them but it will screw their day and that's what we're here for!" 

moderate gratitude. Some officers, like Bobby Crowl who has spent 25 years as a Border Patrol in Campo, California, before retiring, made clear they could use all the help they were getting. Generous donors had even equipped them with a $\$ 16,000$ thermal scope, allowing them to watch human activity in the dark. Border enforcement is a power of the federal government which means that aside from calling the border patrol when they see an illegal crossing, the minutemen can not do anything. And in fact, it is about all they do, being highly aware that going further might backfire on them.

On the first day of the gathering, Carl Braun provided training and guidelines to all the members. Extreme cautiousness was recommended to all campers in order to avoid any type of incident which could potentially lead to negative portrayal in the media. From all these recommendations, it was clear that the last thing minutemen organizers wanted was an undocumented immigrant shot or someone being called a racist. The briefing included recommendations about gun use, emphasizing the rules: guns should be used exclusively for defensive purpose; long arms are offensive weapons so we do not use them; guns should be kept separate from ammunition in the car and loaded only on private property; firearms should not be taken out of the holster until you intend to use them; and technical advice on how not to get hurt. Verbal attacks were equally restricted: "On the radio, call them 'persons of interest', we don't know what they are yet, don't call them illegal;" give them water; "let them know, we do not have a fight with you, we have a fight with our government for allowing this;" call the Border Patrol; wear only one piece of camouflage, not the full outfit to avoid caricatures by the media...

would be easy to just dismiss the minutemen as a group of "wackos" or vigilantes. And there are certainly among them a number of eccentrics such as Britt Craig, known on the border as "Kingfish," a Vietnam veteran who had been living in a van on the border for fifteen months before I met him. But the minutemen movement is also drawing hundreds of mainstream citizens who found an opportunity to voice their fears and anxieties about massive immigration in a welcoming group and to take some action to serve their country they consider to be in danger. Their perceptions are therefore helpful in understanding the resurgence of an anti-immigration sentiment in the mid-2000s in California.

\section{A National Debate}

Our main hypothesis is that the immigration debate has come back to California through the national debate. This appears to be the main explanation for both the revival of the immigration debate in the state and the mobilization of California Minutemen. In the early 2000s, as massive undocumented immigration was growing, there was a push by immigrant advocates to legalize the millions of workers who had no rights and no status in the country and were highly vulnerable to employer abuse. With a Republican majority in Congress under the Bush administration, they clearly needed Republican support to build bipartisan support and were therefore ready to trade-off on border security enforcement and a kind of guest worker program which would at least provide them with basic rights. At the same time, many businesses suffered from labor shortages and were in great demand of immigrant labor, hoping for more flexibility in hiring workers in labor-intensive areas such as construction, agriculture, catering and cleaning services. President Bush was then perceived by both 
sides as a potentially good promoter for comprehensive reform, coming from a border state, Texas, and because he had a moderate position on immigration.

In January 2004, at a press conference, President Bush, asking for the cooperation of Congress to reform immigration laws, proposed a guest-worker temporary program for immigrants who occupy a job "that American citizens are not willing to fill." ${ }^{11}$ At that stage, the president had not fully elaborated the project which soon became the target of numerous criticisms and concerns. The president never introduced legislation and the reform project took on a life on its own. Soon after, that same year, the highly regarded Harvard Professor Samuel Huntington published a very provocative article in the academic journal Foreign Policy, entitled "The Hispanic Challenge." $12 \mathrm{He}$ argued that the persistent influx of Hispanic immigrants threatened to divide the United States into two separate nations, with two cultures and two languages. Along its history, the United States has assimilated waves of immigrants but Huntington believed that this wave was different from the previous ones because of the proximity of the border, the scale of the phenomenon and the regional concentration of immigrants that prevented their assimilation. The argument could have been dismissed by many scholars as blatantly racist if it had not come from such a highly respected figure of political science. Instead, it led to a flow of articles coming from a wide range of social scientists across the country who demonstrated how poorly argued and misleading his paper was. ${ }^{13}$ Yet, the paper echoed concerns shared by many citizens who saw their views about immigration confirmed ${ }^{14}$.

The Minutemen started organizing and publicizing their concerns over the media and the internet in order to put pressure on their representatives to introduce legislation. Some used bumper stickers rating their Congress representatives according to their stance on immigration. Dan Russel, 63, a Campo minuteman from San Diego gave an A+ to Tom Tancredo, Colorado Representative, who supported the House Bill and a F to his local Congress representatives. Their ranks started growing as a number of individuals heard about the movement. They felt less isolated in their concerns and anxieties that are not necessarily easy to voice, particularly in the most liberal areas of the state. Tom, who is married to an Indonesian woman, is a high school teacher in an academy for children with special needs. He enjoys sharing common values with the group. "When you're a conservative living in the Bay area, it's like going to a war zone! People tell me I suffer from over patriotism syndrome because there are 3 or 4 flags in my classroom."

The response from Congress came in December 2005, when the United States House of Representatives passed the Border Protection, Anti-Terrorism and Illegal Immigration Control Act (HR 4437), known as the Sensenbrenner Bill. Among other propositions, the House bill planned to deport 11 million illegal and criminalize undocumented immigrants as well as people helping them. ${ }^{15}$ The Bill had a tremendous impact on the Latino population, fueling fear as well as outrage. On May 1st 2006, the Latinos declared "A Day without Immigrants" and massively demonstrated in the streets of major cities. Hundreds of thousands of undocumented immigrants, primarily Mexicans, came out of the shadow to protest, leaving watchers bewildered: Where did they all come from? How can they be so confident in publicly demonstrating? ${ }^{16}$ The May 2006 demonstrations had a dramatic impact on public opinion and fed the debate over reform. Despite the attempt of the Senate to promote a more moderate counter-bill, 
the word was out that illegals became a political force, that they were everywhere and that a new legislation was being prepared. ${ }^{17}$

In May 2007, one year after the massive protests, the Comprehensive Immigration Reform Bill was introduced in the Senate. It was an attempt to compromise between conflicting demands and needs about immigration: securing the border and providing a legal status and a path to citizenship to the twelve million undocumented immigrants living in the United States. The bill was never voted on and on June 28, a related bill failed in the Senate, ending the process of immigration reform.

This national debate had the effect of radicalizing both sides of the issue. The potential criminalization of illegal immigration had advocacy groups extremely worried and increasingly active. Meanwhile the perspective of a new amnesty of any kind led to the mobilization of anti-immigrant and nativist groups. This was instrumental in building up anti-immigration sentiment in the United-States, which came back to California through activism on both sides and intense media coverage of the national debate.

5. The Role of the Media

The media played a tremendous role in the revival of anti-immigration attitudes in California in various ways. At the turn of the century, the Census Bureau released new data showing that California no longer had a racial majority. For weeks, the focus of many articles was the extent and the diffusion of Hispanic immigration across the territory, with Hispanic becoming the majority in many cities and counties across the state. The maps and reports had a dramatic impact on many people who realized that it was not just their neighborhood being transformed by immigration but the whole state and soon-to-be the whole nation. This heightened the feeling of an invasion on people already inclined to cultural nativism and to worry about the future of the American identity.

The coverage of Samuel Huntington's argument was equally generous. The argument that the nation was at risk of being split into two nations with two cultures and two languages spread all over the newspapers, reinforcing people's fears and anxieties about massive immigration. The nativism that had always been around was revived by the media. Despite the counter-attack by the vast majority of the scientific community, the idea of a serious threat to American identity dominated the news.

This created a highly favorable context for the minutemen to get their word across. It became much easier for them to get an audience when other people had heard the issues in the news as well. In addition, popular right-wing talk show figures such as Rush Limbaugh and Lou Dobbs kept the debate and sense of threat going.

Most of the minutemen I met acknowledged that they first heard about their organizations in the media. They then went on the Internet to learn more about the movement, the issue of immigration, and the membership process. Many acknowledged their frustration at immigration rates about which they could do noting. They felt isolated and expressed relief when they discovered other people were sharing their views and taking some action.

In the end, it is probably the electronic media that played the greatest role. The mainstream media raised people's awareness about the potential threat posed by massive immigration and undocumented immigrants. But as people concerned about immigration sought more information, in a highly divided media market, many resorted to the Internet where they could find all the data likely to reinforce their 
perceptions. The data invalidating their views was equally available but often disregarded. Most of the minutemen I interviewed, told me that they did their own research. They came up with the most extravagant data about the number of illegal aliens entering the US and the impact it had on the country's economy and cultural identity.

To that extent, it is important to remember that the number one issue in the media in the early 2000s was security after the $9 / 11$ terrorist attack. It was clearly the key issue in the 2004 election. According to Mary Beth Cahill, John Kerry's campaign manager, "it was the elephant in the middle of the room and one always had to navigate around that on both sides." ${ }^{18}$

6. The Security Context after $9 / 11$

Since the $9 / 11$ attacks of 2001, the United States has been engaged in a global war against terrorism. The Bush administration has constantly emphasized the threat to the nation's security in order to justify the invasion of Iraq, the escalating military expenditures and the need for a strong leader-namely himself-to protect the country. As a result, airport security and customs checks have been seriously strengthened. The contrast between the security concern at the highest level and what was happening along the border became a source of anxiety and a major argument for the minutemen. How could the government seriously pretend to protect the country from terrorists, did the minutemen ask, while the border was wide open?

The wildest rumors circulate among the minutemen. During the training session, Carl Braun alerted the campers: "Do you know that they found a prayer carpet in Arizona?" He went on explaining that he had himself witnessed people arguing in Arabic language (at least he thought so). Many worried that Muslim terrorists might be changing their names to Latino names. Meanwhile, the border patrol officers I met seemed more concerned with gang members from El Salvador getting rid of their tattoos and pretending to be Mexican to avoid being sent back home. Yet the rumors according to which Al Qaeda might develop ties to the Mara Salvatrucha, also known as MS-13, have reinforced the fears. "What if even a hundred are from a nation that hates America?" asked Braun.

41 It only takes one visit to the border to realize why the prospect of a double fence all along it is unrealistic. The landscape at the border is an alternation of canyons and it would cost billions to build up and maintain, let alone watch. Many worry that even if the southern border were secured, the terrorists might start flowing in from Canada. The minutemen are fully conscious of the limited result of their action. Detention centers are often full. Most of the time, when a Border Patrol catches a group of undocumented immigrants, they put them in a bus to drive them back to the other side of the border even though these immigrants are highly likely to try to come back the next day. According to Border Patrol officer Crowl, he personally has seen someone coming back as much as 37 times. Yet if the border is hard to secure, it has less to do with the immigrants than with the traffic between Mexico and the United States that has developed over the past ten years. In addition to the national debate, there are a number of local circumstances that explain the revival of the immigration debate in California.

7. The Deterioration of Security at the Border

42 Since the operation Gatekeepers under the Clinton administration in 1994, the traditional points of passage have witnessed increased law enforcement. The San 
Diego-Tijuana area has become a tightly watched military zone with a wall that begins in the Pacific Ocean and stretches 14 miles to the east. After 9/11, security was reinforced in checkpoint areas and also in ports and airports. As a result, it became increasingly difficult for smugglers to use the points of passage they had traditionally been using. Most of the traffic moved east until enhanced enforcement along the Arizona border ended up concentrating a great part of the traffic on the California border.

The border has therefore become a much more dangerous place to live and the Border Patrol's main security concern has shifted to drug enforcement according to retired Border Patrol Bobby Crowl. The minutemen organizers gave extensive warning to the campers about the groups of people carrying big backpacks and usually rifle guns. The organizers clearly advised the campers to hide and stay away from them considering how violent they can be. People in the area have complained about the rise in crime and the resulting decline in property values.

The border has also become increasingly dangerous for the undocumented immigrants who cross. They are even more vulnerable to drug runners and "coyotes," immigrant smugglers who now charge very high prices to cross. According to a Border Patrol officer I met in Tecate, crossing the border 15 years ago cost about $\$ 300$. When the Gatekeepers operation was launched in 1994 , it ranged from $\$ 1,000$ to $\$ 1,500$. In 2006 , it could cost as much as $\$ 12,000$. Many of the immigrants are unable to raise such sums. Some end up crossing the way as modern "indentured servants." They commit to work for a gang and sell drugs until they have paid back their debt.

The journey itself across the border has become highly dangerous. Needles with steroids have been found, used by coyotes to keep the group going under difficult conditions. Many people die in the desert weather which can be burning hot during the day and freezing cold at night. Some of the minutemen argued that they actually were concerned about their government letting these people die in the desert and be abused by smugglers. They argued the situation would improve if security was reinforced and appropriate legislation passed.

8. Economic Insecurity and the Struggle of the Middle Class

Although the economy was in much better shape in the mid-2000s than in the early 1990s, there were still a lot of concerns about the burden of illegal immigrants on the state's economy. The economy had been doing well in California up to the subprime crisis but the concerns of minutemen revealed two issues. First, over the past decade, the middle-class has clearly suffered from declining or stagnating real wages, high gas prices and rising costs of the health care system and college fees. The Bush administration tax-cuts benefited the most affluent but hurt the middle-class in a context of severe budget constraints. In addition, job outsourcing had taken its toll on the working class and created a greater economic insecurity among blue collar workers. Many of the minutemen did not believe that immigrants were taking jobs Americans did not want. They rather perceived immigrants as driving the wages down and competing at the bottom of the social scale for unskilled jobs that should be kept for Americans. This has also been a great concern in the African-American community, where many black unskilled workers have reported feeling displaced. Many minutemen argued that these jobs should be going to college kids, although no one could suppress a smile when I asked whether they could really pick-up strawberries in $110 \mathrm{~F}$ weather. Some of them joked that grapes were not being picked up in Sonoma county due to a 
shortage of labor. The economic loss for the wine grower was the price to pay for the exploitation of illegal labor. Dan Russel, a sixty-three-year-old Campo minutemen complained that the entire society had learned to rely on Latino labor force out of laziness: "Everyone looks for a cheap way to get things done: nobody wants to cut lawn, watch children, do their yard. I still cut my own grass, I guess it makes me a real dinosaur!" They all blamed the employers for breaking the rules and the Bush administration for failing to sanction these employers.

Yet the main concern is linked to the legitimate concern that California public and social services are overrun, which is a direct result of tremendous population growth in a sate that doesn't believe in taxes. The taxpayers' revolt, Proposition 13, put a cap on property tax in 1978. California is regularly caught up in budget deadlocks due to resistance to new taxes and frustration at the poor level of performance of the public schools and social services. This generates a vicious circle where the decline in tax revenue leads to poorer public services. This, in turn, increases the defiance in state government and therefore undermines support for taxes. The perception is clear, among the minutemen, that the burden of immigration rests on the taxpayers. Although there is much debate among economists as to whether immigrants contribute more to the economy than they cost in services, the minutemen's argument mostly rests on misinformation. Against all evidence, they believe that undocumented immigrants do not pay taxes and send all their money home. The argument is highly intertwined with racial nativism, as they usually add that immigrants tend to live in ethnic enclaves, watch Latin American TV, do not learn English and do not want to integrate. These are arguments politicians have chosen to push in hope for political gains.

9. Conclusion: The Dangers of the Political Instrumentalization of Fear

In the mid-2000s, the minutemen had become public relations figures. Their whole purpose was to attract attention to the situation at the border. They primarily sought to affect the debate about undocumented immigration and push for legislation. The most visible organizations were acutely aware they were being watched and worked at crafting a positive image. Although many showed concern about the economy, the message they advocated was mostly about securing the border, with constant references to the global war on terrorism in the aftermath of 9/11.

Unlike the Pete Wilson's supporters, they did not get large protesting Latino crowds against them which suggests that they successfully blended patriotism with border protection. They seem to have faded from public view since the $9 / 11$ trauma has receded. Meanwhile, Congress has backed away from immigration reform. But the minutemen served a purpose by putting a public face on border concerns. In this sense, they were the right-wing equivalent of the anti-war protestors and figures such as Cindy Sheehan. As a result, both the press and politicians used them to make points about immigration. Even Governor Arnold Schwarzenegger gave his support to the minutemen and committed to send the National Guard to the border in August 2006. ${ }^{19}$ Just like Pete Wilson in the mid-1990s, many politicians believed that divisive politics and playing on people's fears of invasion and cultural change would pay-off in the short run.

50 To the shock of many observers, tough stands on immigration were adopted in local races by a number of Republicans, leaving middle-of-the-road Republicans not sure about what position to adopt. The immigration issue was heavily used, for example, by 
Brian Bilbray in a Congressional special election in June 2006. The Republican candidate was running in a safe Republican district (California's $50^{\text {th }}$ district in the San Diego area) to replace Randy Cunningham who had resigned on November 28, 2005 after pleading guilty to bribery, wire fraud, mail fraud and tax evasion charges.

The debate was still dividing Congress during the midterm election in 2006, with Congress showing no sign of finding a compromise. The Republicans were therefore caught in a situation where they had made illegal immigration a salient issue that they had proved unable to resolve. It helped in no way to undermine the growing unpopularity of the war in Iraq. In addition, the Federal Governement organized raids in immigrant communities to force undocumented immigrants to depart. Many cities passed "sanctuary city" ordinances, a public statement of their refusal to cooperate with immigration enforcement federal forces. ${ }^{20}$ Meanwhile, the debate on immigration reduced the flow of immigrants and many of the undocumented temporary workers who used to cross the border continuously as seasonal workers became permanent illegals since they feared they would not be able to re-enter the country if they left. Meanwhile, many asked for citizenship and registered to vote.

The November 2008 election demonstrated that the Republican strategy backfired on the party, at the national level this time. Stirring anti-immigration attitudes had clearly hurt the Republican party at the state level in the 1990s. The Latinos massively voted for the Democratic candidate Barack Obama in the 2008 presidential election, by a margin of $67 \%$, with little consideration for the fact he was black. ${ }^{21} \mathrm{John}$ McCain could have chosen to build on the sympathy he enjoyed in the Hispanic community for promoting a rather balanced bi-partisan immigration reform. But in order to reach out to the most conservative branch of his party, he took a much tougher stance on immigration. As a result, the Republican party has probably lost the Latino vote for at least a generation, which in the context of the Latino rapid demographic growth, could harm the future of the Republican electoral base. ${ }^{22}$ In Nevada, New Mexico, Colorado and even Florida the new Hispanic voters delivered the margin Obama needed to win. The Republicans lost all their Congress seats in New Mexico, a state that George Bush had won by 6,000 votes in 2004 and that registered 40,000 new Hispanic voters. (We Are America Alliance, 2008 23 ) “Today we march. Tomorrow we vote," read the signs of the Latino demonstrators in May 2006. In November 2008, the title on the homepage of "We Are America Alliance" said it all: "We did it!"

\section{NOTES}

1. The Minuteman Project <www.minutemanproject.com/>

2. The term "minutemen" is a direct reference to the civilians who volunteered to join the militia during the years before the Revolution. They were named for their ability to be prepared to fight the British with one minute's notice. 
3. The President's News Conference in Waco, TX, Weekly Comp. Presidential Doc. 509, March 23, 2005. President Bush made the comment in a meeting with Mexican President Vicente Fox and Canadian Prime Minister Paul Martin. 4. I.L. Morris, "African American Voting on Proposition 187: Rethinking the Prevalence of Interminority Conflict," Political Research Quarterly 53.1 (2000): 77-98; J.D. Hovey, et al., "Proposition 187 Reexamined: Attitudes Toward Immigration Among California Voters," Current Psychology 19 (Fall 2000): 159-174; C.J. Tolbert and R.E. Hero, "Race/ethnicity and Direct Democracy: An Analysis of California's Illegal Immigration Initiative," Journal of Politics 58.3 (1996): 806-818.

5. The Minuteman Civil Defense Corps www.minutemanhq.com/hq/ 6. B.E. Cain and K. Mac Donald, "Race and Party Politics in the 1996 U.S. Presidential Election" in M.B. Preston, B.E. Cain and S. Bass, eds., Racial and Ethnic Politics in California, IGS Press, Berkeley, 1998: 296; C.R. Chandler and Y. Tsai, "Social factors influencing immigration attitudes: an analysis of data from the General Social Survey." Social Science Journal 38(April 2001): 177-189; California Opinion Index 1995. Summary Analysis of Voting in the 1994 General Election. The Field Institute. San Francisco, California.

7. Cain and Mac Donald, "Race and Party Politics," 299.

8. R.J. Sonenshein and S.H. Pinkus, "Latino Incorporation Reaches the Urban Summit: How Antonio Villaraigosa Won the 2005 Los Angeles Mayor's Race," Political Science and Politics 38 (2005): 713-721.

9. Field Poll 2000, The Expanding Latino Electorate. Release \#1960, May 1; M. Fiorina, and S.J. Abrams, "Is California Really a Blue State? The New Political Geography of California (Berkeley CA: Berkeley Public Policy Press, 2008), 291-308.

10. http://www.splcenter.org/intel/intelreport/article.jsp?sid=413

11. January 7, 2004: "President Bush Proposes New Temporary Worker Program," White House Press Release.

12. S. Huntington, "The Hispanic Challenge," Foreign Policy (March-April 2004). 13. F. Douzet, "Le cauchemar hispanique de Samuel Huntington," Hérodote 115 (2004): 31-52.

14. Citrin, J. et al., Testing Huntington: Is Immigration a Threat to American Identity? Perspectives on Politics (March 2007).

15. J. Weissman, "House Votes to Toughen Laws on Immigration," Washington Post, 17 December, 2005.

16. Gorman, A. et al., "Marchers fill L.A.'s streets," Los Angeles Times, 2 May 2006. 17. The bipartisan Comprehensive Immigration Reform Bill was voted down by the Senate in June 2007.

18. K.H. Jamieson, ed., Electing the President, 2004 (Philadelphia: University of Pennsylvania Press, 2006), 32.

19. T. Watanabe and M .Finnegan, "Rove tells of 'shared values' with Latinos," Los Angeles Times, 12 July 2006.

20. N. Gaouette, “GOP’s Bitter ‘Sanctuary’ Dispute," Los Angeles Times, 30 November 2007. 
21. M.H. Lopez, "The Hispanic Vote in the 2008 Election," Pew Hispanic Research Center. Updated on November 7, 2008 ; Leal, D. L., Nuno, S. A., Lee, J., Garza, R.O. de la 2008. Latinos, Immigration, and the 2006 Midterm Elections, PS: 309-317. 22. B. Cain, F. Douzet, and H. Lefebvre, "La nouvelle carte politique des EtatsUnis," Hérodote 132 (2009): 60-81.

23. We Are America Alliance <www.weareamericaalliance.org/>

\section{ABSTRACTS}

This paper examines the role of the Minutemen in building up popular pressure for immigration reform and capturing the growing frustration of some of residents at the way the Bush administration is handling immigration in a context of heightened fear about national security. The immigration issue in California had quieted down after anti-immigration proposition 187 was passed -yet never enacted-in 1994. Pete Wilson had unsuccessfully used this divisive issue to win presidential nomination, alienating minority voters in the State and therefore undermining the strength of the Republican party.

Despite an apparent growing tolerance about diversity and good economic times, the issue came back to California both through the deterioration of the situation at the border and through the national debate over immigration reform in the mid-2000s. Based on field work at the CaliforniaMexican border, the author gives a portrait of the Minutemen, explaining their motivations, hopes, fears and action which help understand the perceptions and strategies of congressmen and legislators and the fascinating radicalization of their positions on immigration over the past two years.

\section{INDEX}

Keywords: California, Jim Gildchrist, Cruz Bustamante, Pete Wilson, Campo, Jacumba, San Diego, United States, Karin Mac Donald, Bruce E. Cain, Latin America, Asia, Gray Davis, Minutemen Project, Chris Simcox, Minuteman Civil Defense Corps, Carl Braun, Tim Donnelly, Southern Poverty Law Center, Joseph Fong, Dan Russel, Bobby Crowl, Britt Craig, Texas, Arizona, Samuel Huntington, Tom Tancredo, George Bush, Sensenbrenner, Rush Limbaugh, Lou Dobbs, Mary Beth Cahill, John Kerry, El Salvador, Mexico, Al Qaeda, Mara Salvatrucha, Canada, Tijuana, Pacific Ocean, Tecate, Cindy Sheehan, Arnold Schwarzenegger, Randy Cunningham, Barack Obama, John McCain, Nevada, New Mexico, Colorado, Florida., Minutemen, national identity, immigration reform, class, labor, nativism, U.S. Latino/as, Hispanics

\section{AUTHOR}

\section{FRÉDÉRICK DOUZET}

Frédérick Douzet, Institut Français de Géopolitique, Université Paris 8, France. 